\title{
Animal Welfare Assurance - Impacts on Cattle Production and Export Markets
}

\author{
Suzanne T. Millman ${ }^{1}$
}

\begin{abstract}
Given the strong and sustained public interest in animal welfare, globally sustainable agricultural systems must include animal welfare within the areas of consideration. Animal welfare relates to an animal's quality of life and can range from very good to very poor. A number of conceptual frameworks have been proposed for animal welfare and humane animal care. To varying degrees, these frameworks include aspects of animal health and animal behavior, with relative importance of these criteria weighted by ethics or values. Animal care standards may be dictated by legislation, but are increasingly governed through purchasing decisions by food companies and retailers. Animal welfare assessment protocols that include animal-based parameters provide farmers with benchmarking data for comparison between and within farms, as well as flexibility to modify husbandry or housing when addressing weaknesses within the farm system. Within the laboratory and on commercial farms, researchers are identifying solutions to key animal welfare issues in cattle production, including painful husbandry procedures, restrictive housing and cow comfort, calf feeding, care of the compromised cow and low stress handling.
\end{abstract}

Keywords: Animal behavior, animal welfare assessment and auditing, sustainable livestock production

\section{Garantía del Bienestar Animal - Impactos sobre la producción ganadera y mercados de exportación}

Resumen. Dado el interés en el bienestar animal, los sistemas agrícolas globales sostenibles deben incluir el bienestar animal dentro de las áreas de consideración. El bienestar animal está relacionado con la calidad de vida de un animal y puede variar desde muy buena hasta muy mala. Un número de marcos conceptuales han sido propuestos para el bienestar animal y para el cuidado humano. Con algunas variaciones, estos marcos incluyen aspectos de sanidad y comportamiento animal, con una importancia relativa de estos criterios sopesado por la ética y los valores. Los estándares de cuidado animal pueden dictarse a través de legislación, pero están gobernados más por las decisiones de compra de compañías procesadoras y minoristas. Los protocolos de evaluación del bienestar animal que son incluidos en los parámetros proveen a los productores con información comparativa entre y dentro de granjas, al igual que la flexibilidad para modificar prácticas de reproducción o alojamiento al lidiar con las debilidades dentro del sistema de granja. Dentro del laboratorio y en granjas comerciales, los investigadores pueden identificar soluciones para los problemas del bienestar animal en la producción de ganado, incluyendo procedimientos que causan dolor, alojamiento restrictivo y el confort del ganado, alimentación de terneros, cuidado de vacas con problemas y un manejo de estrés reducido.

Palabras clave: Comportamiento animal, evaluación del bienestar animal y auditoría, producción sostenible.

\section{Introduction}

The concept of animal welfare is distinct from human responsibilities and concepts of animal care or animal protection. Animal welfare is a continuous variable, measured on a sliding scale from "very good" to "very poor", which is measured at the individual level. The World Organization for Animal Health (OIE) included animal welfare in its 2001-2005 Strategic Plan, and defined animal welfare in the Terrestrial
Animal Health Code as follows:

"Animal welfare means how an animal is coping with the conditions in which it lives. An animal is in a good state of welfare if (as indicated by scientific evidence) it is healthy, comfortable, well nourished, safe, able to express innate behavior, and if it is not suffering from unpleasant states such as pain, fear, and distress.

\footnotetext{
${ }^{1}$ Department of Veterinary Diagnostic and Production Animal Medicine \& Department of Biomedical Sciences, lowa State University, Ames, lowa, 50011, United States. Email: smillman@iastate.edu
} 
Good animal welfare requires disease prevention and appropriate veterinary treatment, shelter, management and nutrition, humane handling and humane slaughter or killing. Animal welfare refers to the state of the animal: the treatment that an animal receives is covered by other terms such as animal care, animal husbandry, and humane treatment." (OIE, 2008)

In discussions about sustainable development, it is not always intuitive how animal welfare fits in. In the 1992 United Nations' Conference on Environment and Development (the Earth Summit), sustainable development was portrayed with three key goals: social justice, economic development and environmental protection. Although animal welfare does not fit into any of these goals keys, it is increasingly recognized as an inherent value. Sustainable farming systems are expected to work with recognition that livestock and poultry are sentient beings that experience pleasure, pain, wants and desires (Rawles 2008). Similarly, ethicist Bernard Rollins (1995) refers to an ancient contract associated with farming, terms of animal husbandry and environmental stewardship. Hence, animal welfare is among the metrics in which livestock production practices are judged, together with ecological impacts, sustainability of rural communities, food safety, food security or food distribution.

\section{Public Concern for Animal Welfare}

In many cultures, kindness to animals is considered to be a virtue. In most countries, domesticated animals are considered property, with owners obliged to provide certain levels of care. Conversely, it is commonly believed that humans do not have responsibilities toward animals that are wild or feral domesticated animals. In the U.S., animal protection laws typically differentiate between species kept for companionship versus agricultural species, with abuse or neglect of companion animals treated with greater seriousness and higher penalties than farmed species. In the United States, $56 \%$ of households include pets, and $63 \%$ of pet owners consider their pets to be family members (AVMA 2012). The significance of human-animal bond was evident when Hurricane Katrina hit the Southern U.S. in 2005, and was identified as a factor affecting the evacuation effort. As a result, the U.S. enacted the
Federal Pet Evacuation and Transportation Standards (PETS) Act (H.R. 3858) in 2006, which requires emergency planning agencies to develop infrastructure that ensures pets are evacuated with their owners. Greater concern is also given to species for which there is evidence of sentience, or the capacity to experience feelings of pleasure or pain. In 1997, the Treaty of the European Union was amended by the Amsterdam Treaty, which conferred special legal status to animals:

"Desiring to ensure improved protection and respect for the welfare of animals as sentient beings, have agreed upon the following provision, which shall be annexed to the Treaty establishing the European Community, in formulating and implementing the Community's agricultural, transport, internal market and research policies, the Community and the Member States shall pay full regard to the welfare requirements of animals, while respecting the legislative or administrative provisions and customs of the Member States relating in particular to religious rites, cultural traditions and regional heritage."

An U.S. survey funded by the American Farm Bureau revealed strong public concern for the welfare of farmed animals. Ninety-five percent of respondents agreed with the statement "It is important to me that animals on farms are well cared for" (Lusk and Norwood 2008). Respondents also reported that the government should take an active role in promoting animal welfare $(68 \%)$ and were willing to vote for a law requiring farmers to treat their animals better (75\%). Similarly, in a 2015 consumer survey of public opinion in the U.S., participants were asked to rank their level of concern associated with 12 life issues. Humane treatment of farm animals did not rank in the top five issues, but was identified as a concern by $47 \%$ of respondents (Center for Food Integrity 2015). Most respondents $(60 \%)$ strongly agreed with the statement "if farm animals are treated decently and humanely, I have no problem consuming meat, milk and eggs". However, only $25 \%$ strongly agreed with the statement "U.S. meat is derived from humanely treated animals", and $53 \%$ strongly agreed with the statement "I would support a law in my state to ensure the humane treatment of farm animals". With regard to transparency on issues of animal welfare, consumers 
primarily hold food companies responsible (49\%) relative to farmers $(30 \%)$, grocery stores $(11 \%)$ and restaurants $(10 \%)$. There is evidence that the public views animal welfare concerns to be integrated with issues of public health, food safety and environmental impacts rather than as an isolated issue (Pew Commission on Industrial Farm Animal Production 2008).

\section{How Can we Measure Animal Welfare?}

Animal welfare standards require scientific knowledge about animal biology to determine the physiologic, health, environmental and behavioral needs and responses. At the same time, there are ethical and value based judgments underpinning these scientific approaches and the relative weight placed on particular aspects of an animal's quality of Ifie (Croney and Millman 2007). Animal welfare policy frameworks have also traditionally focused on poor states of animal welfare. For example, the following Five Freedoms developed by the Farm Animal Welfare Council in the UK (http://www.fawc.org.uk):

1. Freedom from hunger and thirst, by ready access to water and a diet to maintain health and vigor

2. Freedom from discomfort, by providing an appropriate environment

3. Freedom from pain, injury and disease, by prevention or rapid diagnosis and treatment

4. Freedom to express normal behavior, by providing sufficient space, proper facilities and appropriate company of the animal's own kind

5. Freedom from fear and distress, by ensuring conditions and treatment, which avoid mental suffering

More recently, the concept of animals having "a life worth living" is also expressed in discussions of animal welfare (Mellor 2016). Dawkins (2008) articulates a simpler approach for defining good animal welfare, which she relates to situations where "animals are healthy and have lives in which they have most of the things they want". This approach accommodates positive states of welfare, such as contentment and pleasure, and maps more closely on outcomes that can be measured scientifically in a laboratory. Cattle health can be evaluated using mortality and morbidity data, growth, biomarkers of stress and immune function and reproduction. Similarly, we can use behavior to "ask" animals about their preferences, quantifying their behavioral responses and using consumer demand theory to examine their willingness to work for access to a particular resource.

David Fraser and his colleagues (1997) point out that public concerns about animal welfare generally fall into three basic concepts, relating to biological function, feelings and natural living. Some of these same concepts map on animal welfare assurance programs. Fraser (2006) identified four categories of animal care requirements commonly associated with these programs. Type 1 requirements relate to provisions that relate to the basic health and biological functioning of the animal, impacting mortality, morbidity, reproduction and growth. Examples of Type 1 requirements relating to cattle production stocking density and bunk space, provision of feed and water, control of parasites, vaccinations and pen hygiene. Type 2 requirements relate to affective states or feelings experienced by animals, such as pain, fear, distress, hunger and discomfort. Examples of Type 2 requirements relating to cattle production include disbudding and castration practices, timely euthanasia of compromised cattle, and restrictions on electric prod use. Type 3 requirements provide opportunities for animals to express natural behavior, especially those that animals are highly motivated to perform. Examples of Type 3 requirements relating to cattle production include access to pasture for grazing, space for locomotion and group housing for expression of social behavior. Type 4 requirements provide opportunities for animals to experience aspects of a natural environment. Examples of Type 4 requirements relating to cattle production include access to pasture, not just for grazing but also for access to sunlight and fresh air.

\section{What Animal Welfare Issues are Affecting Global Cattle Production?}

Alternatives to painful husbandry procedures. Husbandry procedures that cause pain, such as castration and dehorning surgeries, are consistently cited as key societal concerns. Although dairy producers concede that these routine surgeries are painful, analgesic drugs are rarely provided (Misch et al., 2007; Fajt et al., 2011). Pain is a subjective experience; consequently, pain is only known to the person (or animal) who is feeling it. However, we can diagnose pain through changes in an animal's behavior, physiological responses, endocrine biomarkers and nociceptive thresholds (Millman 2013). 
For example, dehorning surgery is associated with increased frequency of ear flicking behavior, increased heart and respiratory rates, and increased plasma cortisol (Heinrich et al. 2009; 2010; Duffield et al. 2010). Pressure algometry (Figure 1) can be used to ask cattle to "rate their pain", by quantifying changes in nociceptive threshold as determined by the pressure at which calves display withdrawl responses (Heinrich et al. 2010). All of these responses are mitigated when local anesthesia and non-steroidal anti-inflammatory drugs are used. In several countries, analgesia is required for dehorning surgery, but is not necessary when calves are disbudded at young ages. Analgesia use adds to cost of production, particularly when administered by a veterinarian. Alternatively, selection of polled genetics may be a more attractive option for some producers.

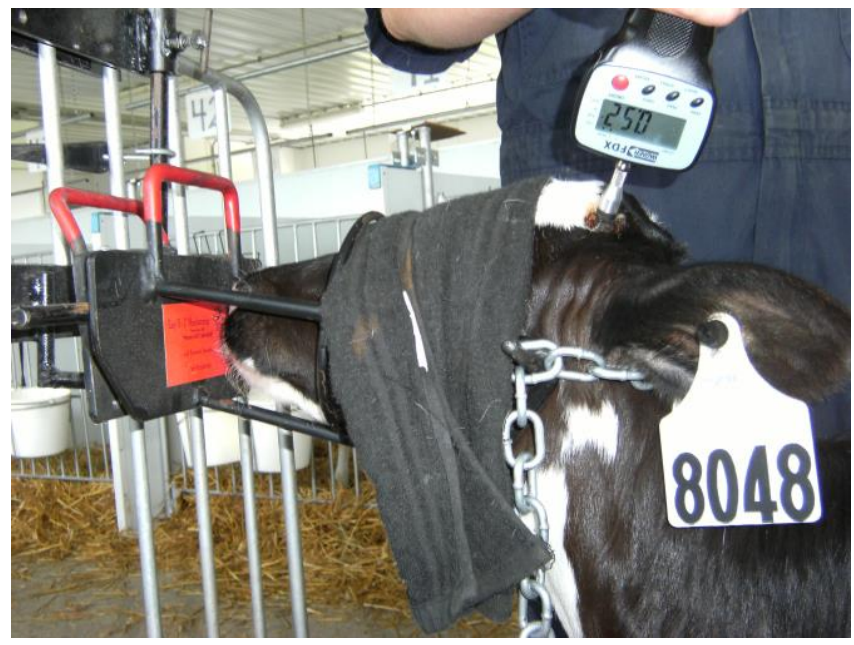

Figure 1. Pressure algometry as applied to the poll of a calf following disbudding surgery. The nociceptive threshold is the maximum pressure that the calf tolerates before displaying a withdrawl response.
Alternatives to restrictive housing. Across farm animal species, criticism is directed at restrictive housing systems that fail to accommodate most natural behaviors. This issue primarily affects the dairy industry, where cows typically receive little or no access to pasture, and calves are traditionally housed individually in stalls. In addition to thwarting of motivation to graze and exercise, poorly managed stall housing presents risks for developing lesions or pressure sores. Animal welfare assessment protocols typically include engineering or resource-based measures, such as stall dimensions or depth of bedding, as well as animal based measures of cow comfort.

In a study of dairy cows tethered in tie-stalls, stall dimensions were less than the recommended engineering standards on $90 \%$ of farms. However, animal based performance ranged between farms, particularly in the lowest quartile (Table 1). Despite poor performance relative to the recommended stall dimensions, some farmers managed the system in a manner that produced perfect scores for animal-based criteria.

Training farmers how to use animal-based measures of animal welfare facilitate animal welfare improvements, since data can be compared between farms or within the same farm over time. This outcome-based approach also provides farmers with flexibility to correct weaknesses according to the specifics of their farm management system and preferences. For example, high prevalence of hock lesions can be corrected by changing the engineering design of the stalls (a costly option), by increasing the amount or type of bedding used in the stalls or by providing cows with more time outside the stall in a pasture or dry lot.

Table 1. Prevalence of select animal welfare indicators as measured on 17,893 cows housed on 317 dairy farms in Ontario, Canada (Zurbrigg et al. 2005).

\begin{tabular}{lcl}
\hline Parameter & Best 20\% of Farms & Worst 20\% of Farms \\
\hline Swollen hocks & $0-4 \%$ of cows & $26-61 \%$ of cows \\
Hock wounds & $0 \%$ of cows & $12-100 \%$ of cows \\
Neck lesions & $0 \%$ of cows & $4-48 \%$ of cows \\
Dirty hind legs & $0-3 \%$ of cows & $36-94 \%$ of cows \\
Hind claw rotation & $0-7 \%$ of cows & $34-74 \% 36-94 \%$ of cows \\
Broken tails & $0 \%$ of cows & $5-50 \%$ of cows \\
\hline
\end{tabular}


Millman: Animal Welfare Assurance - Impacts on Cattle Production and Export Markets

Alternatives to restrictive feeding. Traditional feeding of dairy calves involves restricted intake of fluid milk at a rate of $8-10 \%$ of birth body weight. However, calves restricted to this level of feeding display significantly more behavioral signs of hunger than calves fed larger rations (de Passille et al. 2011; de Vieira et al. 2008). In contrast, enhanced feeding practices are becoming widely adopted and facilitate faster growth and reduce behaviors signs of hunger. Enhanced feeding systems are particularly common in group housing systems for veal calves and replacement heifers, due to risks associated with cross sucking and competition with restricted feeding programs. Despite its benefits, free access milk feeding has potential for bacterial contamination when fed at ambient temperatures. Acidification using formic acid to $\mathrm{pH} 4.0-4.5$ has been shown to significantly reduce coliform and aerobic bacterial growth relative to untreated milk, but additional preservative methods are needed in warm weather (Todd et al. 2010). Acidification is associated with reduced milk intake relative to untreated milk, but not affect pre- or postweaning performance.

Care of compromised cattle. III and injured cattle present particular animal welfare risks associated with malaise and lethargy, capacity to respond to additional stressors such as transport and decision making about humane endpoints. Guiding principles for addressing the needs of ill and injured cattle are beginning to emerge in industry documents, and vary with respect to details provided. Hospital pens are those in which ill or injured animals may be housed for specialized individual care, observation and treatment, and may be referred to as treatment pens, relief pens, and sick pens.

In several European countries, hospital pens must be provided for isolation of sick animals due to concerns about animal welfare and antimicrobial use. In a survey of dairy producers in lowa (Fogsgaard et al. 2015), $82 \%$ had the possibility to house a sick or injured cow away from her normal home pen. Cow well-being was considered either an important or very important reason for moving cows into hospital pens by $80 \%$ of respondents, and cow comfort was cited as important or very important by $70 \%$ of respondents. However, ill and injured cows were frequently housed together with newly freshened cows (45\%), cows close to calving $(35 \%)$, calving cows $(36 \%)$, dry cows $(15 \%)$. This mixing of ill and injured cows together with periparturitent cows is of concern on health and behavior grounds. Sickness behavior associated with proinflammatory cytokines results in different behavioral priorities in ill and injured cows, (Millman 2008) and conflicts with restlessness and protective behaviors of the calving cow. Proudfoot et al. (2014a) showed that cows with mastitis, metritis, pneumonia, or some combination seek isolation during illness. Dairy cows with metritis, mastitis or pneumonia also tended to display more lying behavior than a healthy control group (Proudfoot et al. 2014b).

Low stress handling. Negative experiences during handling have been associated with reduced rate of gain in cattle (Petherick et al. 2003), whereas gentle human-animal interactions have been associated with reduced stress response and handling ease (Krohn et al. 2001; Curley et al. 2006). Refinements to cattle handing have been popularized in the United States in layman journals, seminars and presentations. Low stress handling protocols typically build upon concepts of desensitization of cattle to sight, sound and smells associated with handling chutes in advance of postweaning processing procedures (vaccination, ear tagging, and treatment for disease).

Acclimation refers to the practice of structured introductions of cattle to new environments or stimuli, such as pen resources, alleyways and working facilities prior to processing in order to decrease stress (Noffsinger 2014). Compared to conventionally handled cattle, well-acclimated cattle are expected to exhibit less disorganized, unpredictable herd movement, to rest in all areas of the home pen and to readily use novel water and feed resources. In addition to animal welfare benefits of decreased fearfulness, a pilot study conducted at lowa State University suggested performance benefits in terms of superior average daily gain in cattle that received acclimatization and low stress handling when compared to conventionally handled calves (Dewell et al. 2013).

\section{Summary}

Animal welfare is measured according to the experience of the individual animal, using multidisciplinary approaches of behavior, physiology, animal health and performance. The welfare of farmed animals has broad and sustained public interest; consequently, globally sustainable agricultural systems must include animal welfare within the areas of 
consideration. Animal welfare assessment tools, including animal based outcome criteria, provide benchmarking information helpful for refining best practices. Advances in animal welfare science are central to identifying risks and effective interventions for humane animal care, particularly as alternative housing and husbandry practices are proposed.

Acknowledgements. This manuscript was prepared for the Emsinger International Conference entitled "Cattle production now and in the future in Latin America". The author gratefully acknowledges the hosting institutions associated with this conference: Zamorano University, Tegucigalpa, Honduras and lowa State University, Ames, lowa, USA.

\section{Literature Cited}

AVMA [American Veterinary Medical Association], 2012. U.S. Pet Ownership \& Demographics Sourcebook. Accessed online: https://www.avma.org/KB/Resources/Statistics/Pages/M arket-research-statistics-US-pet-ownership.aspx

Center for Food Integrity. 2015. A clear view of transparency and how it builds consumer trust. 2015 Consumer Trust Research. The Center for Food Integrity, Gladstone, MO, USA. Accessed online: http://www.foodintegrity.org/research/

Croney C., and S.T. Millman, 2007. Board Invited Review: The ethical and behavioral bases for farm animal welfare legislation. Journal of Animal Science 85:557565.

Dawkins, M.S. 2008. What is good welfare and how can we achieve it? In M. S. Dawkins and R. Bonney (eds.). The Future of Animal Farming. Blackwell Publishing, Oxford, UK. p 73-82.

De Passille, A.M., T.F. Borderas, and J. Rushen, 2011. Weaning age of calves fed a high milk allowance by automated feeders: effects on feed, water and energy intake, behavioural signs of hunger, and weight gains. Journal of Dairy Science 94:1401-1408.

Dewell, G.A., R.D Dewell, T. Noffsinger, S.T. Millman, and L.J. Sadler ${ }_{2}$ 2013. Impact of low stress cattle handling on calf health and performance. Proceedings of the 2013 Summer Academy of Veterinary Consultants Conference, Colorado Springs, CO., Aug. 1-3, 2013.

Duffield, T.F., A. Heinrich, S.T. Millman, A. de Haan, S. James, and K. Lissemore. 2010. Reduction in pain response by combined use of local lidocaine anesthesia and systemic ketoprofen in dairy calves dehorned by heat cauterization. Canadian Veterinary Journal 51:283288.
Fajt, V.R., S.A. Wanger, and B. Norby. 2011. Analgesic drug administration and attidudes about analgesia in cattle among bovine practitioners in the United States. Journal of the American Veterinary Medical Association 238:755-767.

Fogsgaard, K.K., M.S. Herskin, P.J. Gorden, L.L. Timms, J.K. Shearer, and S.T. Millman. 2016. Management and design of hospital pens relative to behavior of the compromised dairy cow: a questionnaire survey of lowa dairy farms. Applied Animal Behaviour Science, Special Issue: Behaviour of Sick Animals 175:50-55.

Fraser, D. 2006. Animal welfare assurance programs in food production: a framework for assessing the options. Animal Welfare 15:93-104.

Fraser, D., D.M. Weary, E.A. Pajor, and B.N. Milligan. 1997. A scientific concept of animal welfare that reflects ethical concerns. Animal Welfare 6:187-205.

Heinrich, A., T.F. Duffield, K.D. Lissemore, E.J. Squires, S.T. Millman, 2009. The impact of meloxicam on postsurgical stress associated with cautery dehorning. Journal of Dairy Science 92:540-547.

Heinrich, A., T.F. Duffield, K.D. Lissemore, D.L. Pearl, and S.T. Millman, 2010. The effect of meloxicam on behavior and pain sensitivity of dairy calves following cautery disbudding with a local anesthetic. Journal of Dairy Science 93:2450-2457.

Lusk, J.L., and B.F. Norwood. 2008. A survey to determine public opinion about the ethics and governance of farm animal welfare. Journal of the American Veterinary Medical Association 233:1121-1126.

Mellor, D.J., 2016. Updating animal welfare thinking: moving beyond the "Five Freedoms" towards "A Life Worth Living". Animals 6:21.

Millman, S.T., 2008. Aiding convalescence: using behavior of the compromised animal to improve animal welfare. $1^{\text {st }}$ Boehringer-Ingelheim Expert Forum on Farm Animal Well-being, Cardona, Spain, June 6-7, 2008, pp.17-21.

Millman, S.T. 2013. Behavioral responses of cattle to pain and implications for diagnosis, management and animal welfare. Veterinary Clinics of North America, Food Animal 29, 47-58.

Misch L.J., T.F. Duffield, S.T. Millman, and K.D. Lissemore. 2007. An investigation into the practices of dairy producers and veterinarians in dehorning dairy calves in Ontario. Canadian Veterinary Journal 48: 1249-1254.

OIE [World Organization for Animal Health], 2013. Chapter 7.1. Introduction to the recommendations for animal welfare. Terrestrial Animal Health Code. Accessed online:

http://www.oie.int/index.php?id=169\&L=0\&htmfile=chapit re 1.7.1.htm.

Petherick, J.C., R.G. Holroyd, and A.J. Swain. 2003. Performance of lot-fed Bos indicus steers exposed to aspects of a feedlot environment before lot-feeding. Australian Journal of Experimental Agriculture 43:1181. 1191. 
Pew Commission on Industrial Farm Animal Production, 2008. Report: Putting Meat of the Table: Industrial Farm Animal Production in America. Accessed online at http://www.pewtrusts.org/uploadedFiles/wwwpewtrustsor g/Reports/Industrial Agriculture/PCIFAP FINAL.pdf

Proudfoot, K.L.,M.B. Jensen, D.M. Weary, and M.A.G. von Keyserlingk. 2014a. Dairy cows seek isolation at calving and when ill. Journal of Dairy Science 97 2731-2739.

Proudfoot, K.L., D.M. Weary, and M.A.G. von Keyserlingk, 2014b. Maternal isolation behavior of Holstein dairy cows kept indoors. Journal of Animal Science 92, 277281.

Rawles, K. 2008. Environmental ethics and animal welfare: re-forging a necessary alliance. In M. S. Dawkins and R. Bonney (eds.). The Future of Animal Farming. Blackwell Publishing, Oxford, UK. p 45-60.
Rollin, B.E. 1995. Farm Animal Welfare: Social, Bioethical, and Research Issues. Iowa State University Press, Ames, lowa, USA.

Todd, C.G., T.J. DeVries, K.E. Leslie, J.M. Sargeant, K. Shore, N.G. Anderson, and S.T. Millman. 2010. Effects of free-access feeding and milk replacer acidification on calf performance and development of digestive anatomy. The First North American Conference on Precision Dairy Management, Toronto, Ontario, Canada (March 2-5, 2010).

Zurbrigg, K., D. Kelton, N. Anderson, and S. Millman. 2005. Stall dimensions and the prevalence of lameness, injury and cleanliness on 317 tie stall dairy farms in Ontario. Canadian Veterinary Journal 46:902-909.

Received for publication on April 19, 2016.

Accepted for publication on July 16, 2016. 